\title{
Prion protein and aging
}

\section{Lisa Gasperini and Giuseppe Legname*}

Laboratory of Prion Biology, Department of Neuroscience, Scuola Internazionale Superiore di Studi Avanzati, Trieste, Italy

\section{Edited by:}

Sophie Mouillet-Richard, INSERM

Unit 1124, France

\section{Reviewed by:}

Mohammed Moudjou, Institut

National de la Recherche

Agronomique, France

Inga Zerr, University Medical Center

Göttingen, Germany

\section{${ }^{*}$ Correspondence:}

Giuseppe Legname, Laboratory of Prion Biology, Department of Neuroscience, Scuola Internazionale

Superiore di Studi Avanzati, Via

Bonomea 265, Trieste 34136, Italy

e-mail: legname@sissa.it
The cellular prion protein $\left(\mathrm{PrP}^{\mathrm{C}}\right)$ has been widely investigated ever since its conformational isoform, the prion (or $\mathrm{PrPSc}^{\text {) }}$, was identified as the etiological agent of prion disorders. The high homology shared by the $\mathrm{PrP}^{\mathrm{C}}$-encoding gene among mammals, its high turnover rate and expression in every tissue strongly suggest that $\operatorname{PrPC}^{C}$ may possess key physiological functions. Therefore, defining $\mathrm{PrPC}^{\mathrm{C}}$ roles, properties and fate in the physiology of mammalian cells would be fundamental to understand its pathological involvement in prion diseases. Since the incidence of these neurodegenerative disorders is enhanced in aging, understanding $\operatorname{PrP}^{\mathrm{C}}$ functions in this life phase may be of crucial importance. Indeed, a large body of evidence suggests that $\operatorname{PrP}^{\mathrm{C}}$ plays a neuroprotective and antioxidant role. Moreover, it has been suggested that $\mathrm{PrPC}$ is involved in Alzheimer disease, another neurodegenerative pathology that develops predominantly in the aging population. In prion diseases, $\operatorname{Pr} P^{C}$ function is likely lost upon protein aggregation occurring in the course of the disease. Additionally, the aging process may alter $\operatorname{PrPC}^{\mathrm{C}}$ biochemical properties, thus influencing its propensity to convert into $\operatorname{PrPSC}$. Both phenomena may contribute to the disease development and progression. In Alzheimer disease, PrPC has a controversial role because its presence seems to mediate $\beta$-amyloid toxicity, while its down-regulation correlates with neuronal death. The role of $\mathrm{PrPC}^{\mathrm{C}}$ in aging has been investigated from different perspectives, often leading to contrasting results. The putative protein functions in aging have been studied in relation to memory, behavior and myelin maintenance. In aging mice, $\operatorname{PrP}^{C}$ changes in subcellular localization and post-translational modifications have been explored in an attempt to relate them to different protein roles and propensity to convert into PrPSc. Here we provide an overview of the most relevant studies attempting to delineate $\operatorname{Pr} P C$ functions and fate in aging.

Keywords: PrP, aging, Alzheimer disease, prion diseases

\section{INTRODUCTION}

The conformational conversion of the cellular form of the prion protein $\left(\mathrm{PrP}^{\mathrm{C}}\right)$ into a $\beta$-sheet enriched isoform denoted as prion $\left(\mathrm{PrP}^{\mathrm{Sc}}\right)$ is central in neurodegenerative pathologies collectively know as prion diseases (Prusiner, 2001).

The $\operatorname{PrP}^{\mathrm{C}}$ is a sialoglycoprotein that is attached to the outer leaflet of the plasma membrane via a C-terminal glycosylphosphatidylinositol (GPI) anchor (Stahl et al., 1990). In the cell $\mathrm{PrP}^{\mathrm{C}}$ may be expressed in different glycosylated forms, corresponding to the variable occupancy of the residues Asn180 and Asn196 (Haraguchi et al., 1989). While the C-terminal domain is folded in ordered and distinctive secondary structures, the $\mathrm{N}$-terminal portion is flexible, unstructured and contains a unique octapeptide repeat (OR) region (Zahn et al., 2000). The OR confers $\operatorname{PrP}^{\mathrm{C}}$ one of its most salient features, i.e., the ability to bind divalent cations, prominently copper and to a lesser extent zinc, nickel, iron, and manganese (Stockel et al., 1998; Jackson et al., 2001; Singh et al., 2010; Arena et al., 2012). Indeed, at physiological $\mathrm{pH}$ copper shows the highest binding affinity (Chattopadhyay et al., 2005; Liu et al., 2011). The importance of copper binding for $\operatorname{PrP}^{\mathrm{C}}$ function is reflected in the high OR structural homology among different species (Hornshaw et al., 1995). Two of the most investigated putative functions for $\operatorname{PrP}^{\mathrm{C}}$ are neuroprotection and defense against oxidative stress, both relevant in neurodegeneration and cell aging (Vassallo and Herms, 2003; Roucou and LeBlanc, 2005; Aguzzi et al., 2008). In agreement with these findings, $\mathrm{PrP}^{\mathrm{C}}$ copper binding sites support the reduction of $\mathrm{Cu}^{2+}$ to $\mathrm{Cu}^{+}$, thus preventing reactive oxygen species (ROS) formation (Liu et al., 2011).

Although contrasting results are likely due to the different experimental protocols employed, $\mathrm{PrP}^{\mathrm{C}}$ is expressed in almost all body organs and tissues, from embryonic to aging stages (Fournier et al., 1998; Goldmann et al., 1999; Sales et al., 2002). However, the expression levels are differently regulated according to the age and tissue distribution. For instance, while $\mathrm{PrP}^{\mathrm{C}}$ shows a high expression in the central nervous system (CNS), where it is differently regulated during development and aging, it is present at very low levels in the liver (Horiuchi et al., 1995; Moudjou et al., 2001; Peralta et al., 2012). The broad homology conservation of the $\operatorname{PrP}^{\mathrm{C}}$-encoding gene among mammalian and avian species (Hornshaw et al., 1995), the expression of the protein in many tissues during the entire lifespan, and its high turnover rate strongly indicate that $\operatorname{PrP}^{\mathrm{C}}$ possesses key physiological roles. However, the definition of $\operatorname{PrP}^{\mathrm{C}}$ 's univocal function is still under debate. 
The $\mathrm{PrP}^{\mathrm{Sc}}$ isoform can form protein aggregates, known as prion deposits, often present as amyloid structures, which can propagate and possibly cause cell death. Despite continuous steps forward toward the definition of the conformational switch mechanism, the trigger of the posttranslational remodeling event is still obscure, especially in sporadic prion disorders. In the inherited forms of prion diseases, a genetic mutation in the openreading frame of the gene leads to amino acid substitutions, which in turn destabilizes the protein structure over time, promoting $\mathrm{PrP}^{\mathrm{C}}$ to $\mathrm{PrP}^{\mathrm{Sc}}$ conversion. In the infective forms, a preformed $\mathrm{PrP}^{\mathrm{Sc}}$-aggregate triggers the conversion of endogenous $\operatorname{PrP}^{\mathrm{C}}$. In the sporadic forms of the disease, several unknown factors may perturb the protein structure, thus favoring $\mathrm{PrP}^{\mathrm{Sc}}$ formation (Prusiner, 1991, 1994).

If a cause-effect relationship between prion deposits and cell death does not always exist (Lasmezas et al., 1997), a probable consequence of $\mathrm{PrP}^{\mathrm{C}}$ conversion into $\mathrm{PrP}^{\mathrm{Sc}}$ is the loss or alteration of its cellular function. Whether this impairment contributes or not to disease development is still under debate. Moreover, $\mathrm{PrP}^{\mathrm{C}}$ is also involved in Alzheimer disease (AD) (Kellett and Hooper, 2009). Whether in $\mathrm{AD} \operatorname{PrP}^{\mathrm{C}}$ mediates neuroprotection or $\beta$-amyloid toxicity is still under investigation.

All these observations, together with the fact that the highest incidence of prion disorders and $\mathrm{AD}$ is in the elderly population, have renewed the interest of scientists in investigating of the role of $\mathrm{PrP}^{\mathrm{C}}$ during aging. The two main topics under study have been: (i) $\mathrm{PrP}^{\mathrm{C}}$ physiological functions in aging models, and (ii) consequent changes in $\mathrm{PrP}^{\mathrm{C}}$ biochemical properties. The latter may be triggered by the cellular aging process and may promote prion aggregate formation. To date, studies into $\operatorname{PrP}^{\mathrm{C}}$ role in aging are contrasting, mostly due to different animal/cellular systems employed and the lack of consistency in defining aging in experimental models.

Here we provide a comprehensive overview of studies attempting to understand $\mathrm{PrP}^{\mathrm{C}}$ function and fate in aging and relate them to the neurodegenerative processes.

\section{AGING}

In mammals, aging is defined as the accumulation of changes in an individual over time and represents a multifaceted process of social, psychological, and physical alterations (Bowen and Atwood, 2004). Normal aging is associated with significant cognitive declines, such as decreased speed of information processing, working memory capacity, and long-term memory function (Hedden and Gabrieli, 2004). However, changes that occur in aging brains are less linked to chronological time than it was thought in the past. For instance, individual brains may grow old developing less alterations than others (Esiri, 2007).

The study of age-related changes in the human brain is challenging for two main reasons: (i) increasing improvement of nutrition during the last century limits our ability to directly compare human brain samples between generations; and (ii) most elderly brains show some pathological hallmarks, thus complicating the distinction between "normal aging" and "disease" (Esiri, 2007). In the past, it was thought that the main cause of agerelated cognitive decline was massive neuron loss (Brody, 1955) and deterioration of dendritic branches (Scheibel et al., 1976;
Scheibel, 1979). Now we know that alterations occurring in normal aging are more subtle and selective. In fact, it seems that most age-linked behavioral impairments are due to region-specific changes in dendritic morphology, cellular connectivity, calcium dysregulation, gene expression or other factors that affect plasticity and alter neuron network dynamics (Burke and Barnes, 2006). A crucial factor for brain aging is the enormous requirement that neurons have for oxidative metabolism required by energy consumption. Neurons need extraordinary amounts of energy because of: (i) the size and the ensuing energy-consumption system of transport for molecules and organelles; and (ii) the electrical activity for impulse transmission, implying ion gradient maintenance. The high degree of oxidative metabolism generates high amounts of ROS that damage proteins, nucleic acids and lipids, thus interfering with normal cell metabolism and resulting, for instance, in altered gene expression and abnormal protein generation (Esiri, 2007).

Mitochondrial efficiency decline, paralleled by oxidative stress, which occurs with aging, is connected to alterations in calcium homeostasis, in particular to higher calcium content in neuron cytosol after excitatory stimulation. Indeed, glutamate activation of N-methyl-D-aspartate (NMDA) receptors produces a transient elevation in intracellular calcium concentration, which is increased in normal aging. Disruption in calcium homeostasis predisposes aging neurons to more extended damage after stress and eventually leads to cell death by apoptosis (Cowan et al., 2001; Thibault et al., 2001; Esiri, 2007).

In this scenario, $\mathrm{PrP}^{\mathrm{C}}$ may possess different functions: (i) neuron protection from oxidative stress through antioxidant activity, by sensing copper and/or free radical stimuli (Vassallo and Herms, 2003); (ii) modulation of calcium entry through NMDA receptor pore by inhibition of the channel activity (Cowan et al., 2001; Lo et al., 2007); (iii) anti-apoptotic effect on Bax-mediated cell death (Bounhar et al., 2006; Lo et al., 2007).

\section{WHICH MOUSE AGE SHOULD BE CONSIDERED AS AN AGING MODEL?}

For many reasons, researchers often use terms as aged or old mice that may not be proper by definition. A wild-type mouse goes through the following life phases (http://research.jax.org/faculty/ harrison/ger1vLifespan1.html) (Flurkey et al., 2007):

- Mature adult [3-6 months old (mo) mouse]: this period is the reference for any age change; these mice are fully developed, but not senescent; after 6 months of age mice can show some agerelated changes, for instance females are retired from breeding because litter size begins to diminish.

- Middle age (10-15 mo mouse): senescent changes can be detected in some, but not all, biomarkers of aging; these mice are generally used to determine if an age-related change is progressive or occurs only in old age.

- Old (18-24 mo mouse, or older): senescent changes can be detected in almost all biomarkers in all animals.

Taking into account these categories, few studies claiming the use of old mice indeed employ a properly aged model. For the purposes of this manuscript, this point has to be carefully taken into account, especially in respect of studies on $\operatorname{PrP}^{\mathrm{C}}$ biochemical 
property changes in aging. On the other hand, studies on $\operatorname{PrP}^{\mathrm{C}}$ knockout mice (also noted as $\operatorname{Pr} n p^{0 / 0}$ ), when not performed on old animals, as defined above, can nevertheless reveal progressive age-related changes that start earlier because of $\operatorname{PrP}^{\mathrm{C}}$ absence. To let the reader critically consider reported results and conclusions, we will specify for each reviewed study the age of the animals used.

\section{PrPC ROLE IN AGING}

As previously mentioned, $\mathrm{PrP}^{\mathrm{C}}$ is highly conserved and expressed among mammals, and it may play important physiological roles. However, numerous efforts aimed at identifying $\operatorname{PrP}^{C}$ function have harbored contrasting results. Most of the work has focused on the nervous system, which is the organ with the highest $\mathrm{PrP}^{\mathrm{C}}$ expression and the site of prion disease pathology. Several results have linked $\mathrm{PrP}^{\mathrm{C}}$ to many cellular processes, such as neuronal survival, neurite outgrowth, synapse formation/maintenance/functionality, and myelinated fiber formation/maintenance (Aguzzi et al., 2008). However, its expression in many other tissues indicates that $\operatorname{PrP}^{\mathrm{C}}$ has either many different functions or a function compatible with diverse cellular types.

A large body of evidence suggests that $\mathrm{PrP}^{\mathrm{C}}$ plays a role in essential metal homeostasis, resulting in protection from oxidative stress. An overlap between systems controlling essential metal homeostasis and oxygen radical metabolism has been extensively documented (Avery, 2001). For instance, many antioxidant enzymes need metal ions as cofactors. $\mathrm{PrP}^{\mathrm{C}}$ has been associated with cellular systems that control redox balance and protect against oxidative stress (Brown and Sassoon, 2002). Indeed, $\mathrm{PrP}^{\mathrm{C}}$ null models show: (i) increased neuronal sensitivity to oxidative stress (Brown et al., 1997; Rachidi et al., 2003); (ii) alterations of superoxide dismutase 1 (SOD1) activity due to impairments in copper incorporation (Brown and Besinger, 1998; Kralovicova et al., 2009); (iii) higher levels of lipids and protein oxidation (Wong et al., 2001). Moreover, $\operatorname{PrP}^{\mathrm{C}}$ expression is increased by heat shock, hypoxia, ischemia, hypoglycemia, stroke, and knockdown of any SOD protein while shutting down $\mathrm{PrP}^{\mathrm{C}}$ increases extracellular-SOD expression and SOD2 activity (Brown and Besinger, 1998; Shyu et al., 2000, 2004, 2005; McLennan et al., 2004; Mitsios et al., 2007; Kralovicova et al., 2009). Furthermore, in vitro $\mathrm{PrP}^{\mathrm{C}}$ possesses $\mathrm{SOD}$-like activity with a dismutation constant rate similar to SOD2 (Brown et al., 1999, 2001; Cui et al., 2003; Treiber et al., 2007). A possible link between SOD and $\mathrm{PrP}^{\mathrm{C}}$ may be copper. Indeed, SOD activity depends on copper incorporation and probably involves $\mathrm{Cu}^{2+}$ reduction, characteristics shared with $\operatorname{PrP}^{\mathrm{C}}$ (Brown et al., 2001). It should also be noted that $\mathrm{PrP}^{\mathrm{C}}$ is cleaved at the end of the OR through the action of ROS, a process termed $\beta$-cleavage. $\beta$-cleavage is considered an early and critical event in the mechanism through which $\mathrm{PrP}^{\mathrm{C}}$ protects cells against oxidative stress. If a PrP construct lacks the $\mathrm{OR}$, the protein will fail to undergo ROS-mediated $\beta$-cleavage, as occurs with two mutant forms associated with prion diseases (Watt et al., 2005).

\section{PrPC ROLE IN BEHAVIOR AND LEARNING AS A FUNCTION OF AGE}

Two main observations suggest that $\mathrm{PrP}^{\mathrm{C}}$ plays a role in behavior and learning mechanisms in aging: (i) $\mathrm{PrP}^{\mathrm{C}}$ is predominantly expressed in neurons, reaching the highest level in the hippocampus (DeArmond et al., 1987; Benvegnu et al., 2010); (ii) $\mathrm{PrP}^{\mathrm{C}}$ brain expression is increased in aging (Williams et al., 2004). However, studies carried out on $\mathrm{PrP}^{\mathrm{C}}$ knockout mice have sometimes produced contrasting results, likely due to differences in lines and age.

The behavioral characterization of the first $\operatorname{PrP}^{\mathrm{C}}$ knockout (ZurichI) mouse generation was performed in 7 mo mice (Bueler et al., 1992). At this age these mice cannot be considered aged. Nevertheless, the latter study represents a good starting point toward analyzing alterations triggered by $\mathrm{PrP}^{\mathrm{C}}$ ablation. In the swim test and in the Y-maze, $\operatorname{PrPC}^{C}$ knockout mice did not reveal learning impairments, although there were large individual differences within test and control groups. In the two-way avoidance test, in which animals have to avoid an electrical shock announced by a light by running to the opposite chamber of the box, thus involving also motorial ability, $\operatorname{PrP}^{\mathrm{C}}$ knockout mice showed a slightly lower performance, but the great variability in each group hid a possible significant difference. As Büeler and colleagues state, these results should be carefully considered because of the dissimilar loci surrounding $\operatorname{Prn} p^{0 / 0}$ and wild-type $\left(\operatorname{Prnp}{ }^{+/+}\right)$ alleles, due to different genetic background.

However, a follow-up study using the same mouse line showed that $\operatorname{Pr} n p^{0 / 0}$ mouse aging-related behavior alterations could not be ascribed to surrounding loci differences, but to $\operatorname{PrP}^{\mathrm{C}}$ ablation itself (Coitinho et al., 2003). Differently from Büeler and colleagues data, here statistically significant results were obtained by applying other behavioral tests and by increasing the animal age: 9 and 3 mo $\operatorname{Prnp}^{0 / 0}$ and $P r n p^{+/+}$mice were compared in regards to fear-motivated learning, locomotor activity, exploratory behavior and anxiety. Nine mo $\mathrm{PrP}^{\mathrm{C}}$ knockout mice showed impairments in short- and long-term memory and exploratory activity. With exception of the exploratory activity, 9 mo $\operatorname{Prn} p^{0 / 0}$ mouse performances were recapitulated in 9 mo rats injected in the hippocampus with anti-PrP $\mathrm{P}^{\mathrm{C}}$ antibody, thus ruling out the involvement of the surrounding loci in memory alterations in the aging $\operatorname{PrP}^{C}$ knockout line.

Another study concerning aging-related $\mathrm{PrP}^{\mathrm{C}}$ role in behavior control was performed on 3 and 11 mo mice from three lines (wild-type, $\operatorname{Prn} p^{0 / 0}$ and $\mathrm{PrP}^{\mathrm{C}}$ overexpressing Tga20 on a $\operatorname{Prn} p^{0 / 0}$ genetic background) (Rial et al., 2009). Collectively the data showed that $\mathrm{PrP}^{\mathrm{C}}$ overexpressing Tga20 mice were less susceptible to aging-caused alterations in locomotion, anxiety like responses and short-term social recognition memory in comparison with $\operatorname{Prnp}^{+/+}$and $P r n p^{0 / 0}$ mice. On the contrary, $\operatorname{PrP}^{\mathrm{C}}$ knockout mice resulted more susceptible to age-related decline in comparison with wild-type mice. Biochemical analyses revealed that Tga20 mice have lower neuron caspase 3 activation and serum acetylcholinesterase levels, and higher synaptic density. In light of these cognition-enhancing properties, Rial and colleagues suggest in particular the interaction of $\operatorname{PrP}^{\mathrm{C}}$ with the stress-inducible protein 1 as a target for pharmaceutical intervention to attenuate age-related cognitive impairments.

More recent results confirmed age-dependent behavioral abnormalities in ZurichI $\operatorname{PrP}^{\mathrm{C}}$ knockout mice (Schmitz et al., 2014). The following alterations were reported: (i) poor native nest building behavior in young ( $3 \mathrm{mo}$ ) and old (9 and $20 \mathrm{mo}$ ) 
$\operatorname{Pr}^{\mathrm{C}}$ knockout mice; (ii) higher latency in exploring a new environment only in young but not in old $\mathrm{PrP}^{\mathrm{C}}$ knockout mice; (iii) more pronounced drop in anxiety during aging in $\mathrm{PrP}^{\mathrm{C}}$ knockout mice; (iv) decline in associative learning in old $\mathrm{PrP}^{\mathrm{C}}$ knockout mice compared to age-matched wild-type. Schmitz and colleagues wanted to relate the observed behavioral abnormalities to neuron structural alterations in $\operatorname{PrP}^{\mathrm{C}}$ knockout mice. They found $\mathrm{PrP}^{\mathrm{C}}$-dependent alterations in cytoskeletal proteins that are responsible for morphology, structure, and stability of neurons, thus related to learning processes. Indeed, $\mathrm{PrP}^{\mathrm{C}}$ was previously reported to functionally interact with cytoskeletal proteins (Dong et al., 2008; Malaga-Trillo et al., 2009).

Telling's group performed a work on a slightly different line, the ZurichI crossed with wild-type FVB animals (Nazor et al., 2007). On the rotarod, $P r n p^{0 / 0}$ on FVB background mice showed an age-dependent motor behavior deficit in comparison to wildtype, suggesting a function for $\operatorname{PrP}^{\mathrm{C}}$ in maintaining sensorimotor coordination. This difference between wild-type and $\mathrm{PrP}^{\mathrm{C}}$ knockout mice was detected starting from 3 to $8 \mathrm{mo}$. Moreover, these mice at 6 mo revealed vacuolation in different brain regions. Although vacuolation has been rarely reported in $\operatorname{PrP}^{\mathrm{C}}$ knockout mice, Telling and coworkers parallel their findings, concerning both spongiosis and motor impairments, with results from a transgenic murine model expressing the PrP mutation linked to Gerstmann-Sträussler-Scheinker syndrome (GSS), thus suggesting the loss of $\operatorname{PrP}^{\mathrm{C}}$ function as disease mechanism.

Another study was performed by Massimino and colleagues using three groups of congenic mice: wild-type $\mathrm{FVB}, \mathrm{PrP}^{\mathrm{C}}$ knockout on FVB background and $\mathrm{Tg} 46$ mice in which $\mathrm{PrP}^{\mathrm{C}}$ expression was rescued over a $\operatorname{PrP}^{\mathrm{C}}$ knockout background (Massimino et al., 2013). While young ( $3 \mathrm{mo}) \operatorname{PrP}^{\mathrm{C}}$ knockout mice did not show any alteration, aged (15-18 mo) animals revealed perturbed behavioral pattern, in particular difficulties in adapting to new situations and in locomotor activity, likely due to a depressive syndrome. The authors suggest that $\operatorname{PrP}^{\mathrm{C}}$ absence affects emotional reactivity. The authors did not carry out histological analysis of old $\operatorname{Prn} p^{0 / 0}$ mice, therefore, it is not known whether the $\operatorname{PrP}^{\mathrm{C}}$ knockout colony employed showed the vacuolation phenotype observed by Telling's group studying the same mouse line. To our knowledge, the result obtained by Telling's and coworkers is the only one showing vacuolation in $\operatorname{Pr} n p^{0 / 0}$ mice. For instance, Aguzzi and colleagues did not detect any morphological anomaly in 14 mo ZurichI Prnp $p^{0 / 0}$ mice (Bremer et al., 2010).

Taken together, all these studies demonstrate that $\operatorname{PrP}^{\mathrm{C}}$ absence affects learning, cognitive and behavioral skills in aged mice. A possible cause of these alterations is the lack of $\mathrm{PrP}^{\mathrm{C}}$ mediated neuroprotection and reduction of oxidative stress, particularly important to preserve neuron functions in the aging brain milieu.

\section{PrPC ROLE IN MYELIN MAINTENANCE}

Alterations occurring during both normal aging and neurodegenerative pathologies largely involve maintenance and regeneration of myelin structure (Verdu et al., 2000; Peters, 2002; Bartzokis, 2011). Metal ions, in particular copper and iron, are necessary for both myelin formation and maintenance (Skripuletz et al., 2008; Benetti et al., 2010). Therefore, $\operatorname{PrP}^{\mathrm{C}}$ may influence myelin by maintaining copper and iron homeostasis, pathways in which $\mathrm{PrP}^{\mathrm{C}}$ has been involved (Pauly and Harris, 1998; Brown and Harris, 2003; Rachidi et al., 2003; Miura et al., 2005; Singh et al., 2009). By studying 14 mo (middle aged) mice, Aguzzi's group reported that $\mathrm{PrP}^{\mathrm{C}}$ knockout mouse sciatic nerve contains more digestion chambers, i.e., macrophages ingesting myelin debris of degenerating nerve fibers, compared to wild-type mice. Moreover, they showed that $\operatorname{PrP}^{\mathrm{C}}$ expression on neuronal cells, but not on Schwann's cells, is fundamental to preserve myelin fibers and prevent chronic demyelinating polyneuropathy $(\mathrm{CDP})$ in the peripheral nervous system. This finding suggests that neuronal $\operatorname{PrP}^{\mathrm{C}}$ in trans expression is required for a directional communication from axons to Schwann cells (Bremer et al., 2010).

As suggested in a study from our group (Benvegnu et al., 2011), $\operatorname{PrP}^{\mathrm{C}}$ may exert a direct role in myelin sheath formation and structural preservation through its modulation of $\beta$-secretase 1 (BACE1) (Parkin et al., 2007). Results obtained in sciatic nerves from 15 mo mice highlight that $\operatorname{PrP}^{\mathrm{C}}$ influences cleavage and processing of neuregulins. Neuregulins are a class of proteins crucial for myelin maintenance in the peripheral nervous system, and their cleavage by BACE1 is necessary for signaling functions. Hence, $\operatorname{PrP}^{\mathrm{C}}$ positively regulates neuregulin processing, thus affecting their function in myelin homeostasis, maybe by modulating BACE1 activity. Interestingly, in the previously mentioned work, Aguzzi's group showed that CDP is prevented by $\mathrm{PrP}^{\mathrm{C}}$ variants that are permissive for proteolytic amino-proximal cleavage, but not by variants that do not undergo cleavage. Indeed, all transgenic mice showing CDP lacked C1, i.e., the fragment generated by $\alpha$-cleavage, while all transgenic mice in which the CDP was rescued produced high $\mathrm{C} 1$ levels. Hence, the cleavage of $\operatorname{PrP}^{\mathrm{C}}$ seems to be functional for its myelinotrophic role (Bremer et al., 2010).

\section{AGING-RELATED MODIFICATION OF PrPC BIOCHEMICAL PROPERTIES}

The most common occurrence of human prion diseases (about $80 \%)$ is sporadic. This means that a trigger of prion pathologies may be neither a genetic mutation nor an infectious seed, but most likely an unknown alteration that provokes the switch from $\mathrm{PrP}^{\mathrm{C}}$ to $\mathrm{PrP}^{\mathrm{Sc}}$ (Prusiner, 2001). The aging process itself may modify $\operatorname{PrP}^{\mathrm{C}}$ biochemical properties, making the protein more prone to convert into $\mathrm{PrP}^{\mathrm{Sc}}$. For instance, loss of glycosylation in cell models favors $\mathrm{PrP}^{\mathrm{C}}$ acquisition of $\mathrm{Pr}^{\mathrm{Sc}}$-like features (Lehmann and Harris, 1997). Indeed, glycans regulate $\mathrm{PrP}^{\mathrm{C}}$ folding, intracellular trafficking, localization and function on the neuronal surface, thus their pattern modifications can be likely linked to the disease development. $\operatorname{PrP}^{\mathrm{C}}$ biochemical properties that may be altered by cellular changes occurring during the aging process are: expression levels, post-translational modifications, such as glycosylation and phosphorylation, as well as localization in cellular domains, such as inside/outside membrane lipid rafts.

As mentioned in a previous paragraph, analysis of both parenchyma and microvessels revealed higher levels of both glycosylated and unglycosylated $\operatorname{PrP}^{\mathrm{C}}$ in $\mathrm{C} 57 \mathrm{Bl} / 6 \mathrm{~J}$ old (18 and $24 \mathrm{mo}$ ) mice (Williams et al., 2004). Concerning $\operatorname{PrP}^{\mathrm{C}}$ diverse glycosylation isoforms, the three main bands appearing 
in one-dimensional immunoblots are commonly considered corresponding to di-glycosylated $(\sim 35 \mathrm{KDa})$, mono-glycosylated $(\sim 32 \mathrm{KDa})$ and un-glycosylated ( 28 KDa) (Collinge, 2001; Pan et al., 2002). However, by applying a panel of monoclonal antibodies, the presence of additional lower molecular weight bands representing $\mathrm{N}$-terminally truncated $\operatorname{PrP}^{\mathrm{C}}$ isoforms has been shown (Pan et al., 2002). Moreover, two-dimensional immunoblot analysis revealed in human brain more than 50 $\mathrm{PrP}^{\mathrm{C}}$ species which derive from several glycosylation and cleavage combinations. Interestingly, accumulation of aberrant full-length $\mathrm{PrP}^{\mathrm{C}}$ bound to immature N-linked glycans is indeed a common feature of prion disease (Pan et al., 2005a,b,c). Spurred by these findings, Goh and coworkers investigated N-linked glycans on $\mathrm{PrP}^{\mathrm{C}}$ during normal aging in mouse, providing the first glycan profile of full-length and truncated $\mathrm{PrP}^{\mathrm{C}}$ isoforms (Goh et al., 2007). The oldest mice they used were $15 \mathrm{mo}$. First, they found that different mouse lines (i.e., CD-1 and FVB) have different $\mathrm{PrP}^{\mathrm{C}}$ metabolism resulting in isoform heterogeneity. In general, they showed that the truncated form of $\mathrm{PrP}^{\mathrm{C}}$ undergoes a simplification in its glycosylation process during aging, while the amount of complex oligosaccharides on the full-length $\mathrm{PrP}^{\mathrm{C}}$ increases. This finding contrasts with what was observed in aging compared to young cattle (Yoshioka et al., 2010), but resembles what was previously detected in human brains affected by prion disorders (Pan et al., 2005b). It has been shown that $\operatorname{PrP}^{\mathrm{C}}$ glycosylation state may modulate affinity for copper binding (Moudjou et al., 2007). In particular, the nonglycosylated species showed stronger binding to divalent cations (copper and cobalt) in vitro. Therefore, decreasing $\operatorname{Pr}^{\mathrm{C}}$ glycosylation levels during aging may increase copper binding capacity, thus improving $\mathrm{PrP}^{\mathrm{C}}$ antioxidant function. Interestingly, galactose, which has been detected in this study on full-length $\operatorname{PrP}^{\mathrm{C}}$ in aging, is also highly present on $\operatorname{PrP}^{\mathrm{Sc}}$ (Safar et al., 1990). Moreover, sialic acid content increases with aging on the truncated $\operatorname{PrP}^{\mathrm{C}}$ but remains unchanged on the full-length $\operatorname{PrP}^{\mathrm{C}}$. As the authors observe, the presence of anionic residues may modulate $\mathrm{PrP}^{\mathrm{Sc}}$ mobility, thus facilitating its propagation in prion disorders.

As previously mentioned, aging can modify $\mathrm{PrP}^{\mathrm{C}}$ subcellular localization. Indeed, our group reported that $\operatorname{PrP}^{\mathrm{C}}$ moves from detergent soluble membrane fractions to lipid rafts in aged (20-21 mo) mouse hippocampus (Agostini et al., 2013). No differences in the total $\operatorname{PrP}^{\mathrm{C}}$ expression amount were detected, in contrast with what had been previously reported by another group that used the same mouse line and a very similar age but lacked repeated samples, normalization and statistical analysis (Williams et al., 2004). Changes in the cholesterol/sphingolipid ratio has been reported in normal brain aging, and in degenerative disorders, such as $\mathrm{AD}$ (Martin et al., 2010). As cholesterol and sphingolipids are the two main components of lipid rafts, their relative amount influences many cellular pathways, including protein localization (Martin et al., 2008; Trovo et al., 2011). $\operatorname{PrP}^{\mathrm{C}}$ is a GPI-anchored protein, thus bound to lipid rafts and likely affected by agingrelated alterations in membrane composition. $\mathrm{PrP}^{\mathrm{C}}$ shift toward lipid rafts triggered by changes in lipid composition was confirmed using model systems of lipid manipulation. Moreover, decreasing sphingolipids, thus mimicking a juvenile condition, reduced the formation of $\mathrm{PrP}^{\mathrm{Sc}}$ in a cell line model. This suggests that age-related changes influence $\operatorname{PrP}^{\mathrm{C}}$ localization and ensuing propensity to $\mathrm{PrP}^{\mathrm{Sc}}$ conversion (Agostini et al., 2013).

\section{PrPC AND AD}

The most prevalent form of dementia is AD (Burns and Iliffe, 2009). Various factors are conducive to the risk of late-onset AD, in particular old age, genetic factors, family history, a history of head trauma, midlife hypertension, obesity, diabetes, and hypercholesterolemia (Bendlin et al., 2010). AD is characterized by the misprocessing of two proteins: intraneuronal tau and extracellu$\operatorname{lar} \beta$-amyloid peptide (A $\beta$ ) (Querfurth and LaFerla, 2010). A $\beta$ is generated by the aberrant proteolytic processing of the amyloid precursor protein by BACE1. Several studies have been performed to understand if a toxic interaction between $A \beta$ and $\operatorname{PrP}$ exists, but the use of different in vitro or transgenic models has yielded contrasting results (Schwarze-Eicker et al., 2005; Lauren et al., 2009; Balducci et al., 2010; Calella et al., 2010; Chung et al., 2010; Kessels et al., 2010; Morales et al., 2010; Ordonez-Gutierrez et al., 2013). Thus, in this manuscript, we will consider only what has been found by analyzing $\mathrm{AD}$ patient brains. Whitehouse and colleagues found that $\operatorname{PrP}^{\mathrm{C}}$ levels are decreased in $\mathrm{AD}$ patient hippocampus, normal aging hippocampus, and temporal lobe, but not in AD patient temporal lobe (Whitehouse et al., 2010). With exception of $\mathrm{AD}$ patient temporal lobe data, these results are in contrast with what was reported by Saijo et al. (2011), but correlate with the $\mathrm{PrP}^{\mathrm{C}}$ decrease detected in the cerebrospinal fluid of patients affected by different neurological disorders including AD (Meyne et al., 2009). Since $\operatorname{PrP}^{\mathrm{C}}$ inhibits BACE1 (Parkin et al., 2007), $\operatorname{PrP}^{C}$ level reduction may elevate $A \beta$ production. Therefore, Whitehouse and colleagues suggest that $\operatorname{PrP}^{\mathrm{C}}$ decrease is not a secondary consequence, but a primary cause of $\mathrm{AD}$ and, by occurring also in normal aging, increases the incidence of $\mathrm{AD}$ in old individuals. Interestingly, individuals with mutations in the PrP encoding gene generating a truncated form of the protein developed clinical AD symptoms at relatively young age (Kitamoto et al., 1993). In aging, BACE1 activity strongly increases, thus enhancing $A \beta$ production and the possibility of deposit formation. The reduction of $\mathrm{PrP}^{\mathrm{C}}$-mediated BACE1 inhibition due to the decrease in $\operatorname{PrP}^{\mathrm{C}}$ levels may be a cause of the enzyme activity elevation (Whitehouse et al., 2010). Additionally, since $\mathrm{PrP}^{\mathrm{C}}$ is an antioxidant protein (Vassallo and Herms, 2003; Aguzzi et al., 2008), its downregulation likely increases neuron susceptibility to ROS, which rises in normal aging and in $\mathrm{AD}$ (Halliwell, 2006; Zhu et al., 2007), hence contributing to disease progression. However, a decrease in $\operatorname{PrP}^{\mathrm{C}}$ levels in $\mathrm{AD}$ does not exclude that the residual protein mediates some $A \beta$ toxic effects. Besides, it has been recently reported that $\mathrm{A} \beta$ and $\operatorname{PrP}^{\mathrm{C}}$ do interact specifically in AD patient brains (Dohler et al., 2014). This result was obtained by means of a $\operatorname{PrP}^{\mathrm{C}}-\mathrm{A} \beta$ binding assay and size exclusion chromatography, and no binding was detected in non-demented age-matched controls.

Taken together, these results indicate that $\mathrm{PrP}^{\mathrm{C}}$ may be involved in AD. Therefore, its fate in aging is likely related to the molecular mechanisms that induce neurodegeneration. 


\section{CONCLUSIONS}

As presented in this review, relatively few studies have been carried out on the role of aging in the expression and regulation of $\mathrm{PrP}^{\mathrm{C}}$. Nevertheless, these experiments suggest that there may be a correlation between the physiology of the cells in which $\mathrm{PrP}^{\mathrm{C}}$ is present and its localization and processing during aging. Particularly in the CNS, where it is abundantly expressed, $\mathrm{PrP}^{\mathrm{C}}$ plays a prominent role as the precursor of $\mathrm{PrP}^{\mathrm{Sc}}$ and thereby dictates the amount and extension of the conversion and accumulation process of prions. In aging, the physiology and the cellular localization of the protein may change concomitantly to different biochemical milieus in the cell membrane. Indeed, either membrane composition, in particular lipid raft composition, or additional protein complexes proximity to $\mathrm{PrP}^{\mathrm{C}}$, may influence its physiological functions. As indicated in the final paragraph, these changes may have a general relevance for more common causes of dementia such as AD. More work is necessary to define the precise role of $\mathrm{PrP}^{\mathrm{C}}$ in the progression of $\mathrm{AD}$ and perhaps in other neurodegenerative diseases.

\section{ACKNOWLEDGMENT}

The authors would like to thank Kate Pischke and Erica Sarnataro for editing and proofreading the manuscript.

\section{REFERENCES}

Agostini, F., Dotti, C. G., Perez-Canamas, A., Ledesma, M. D., Benetti, F., and Legname, G. (2013). Prion protein accumulation in lipid rafts of mouse aging brain. PLoS ONE 8:e74244. doi: 10.1371/journal.pone.0074244

Aguzzi, A., Baumann, F., and Bremer, J. (2008). The prion's elusive reason for being. Annu. Rev. Neurosci. 31, 439-477. doi: 10.1146/annurev.neuro.31.0604 07.125620

Arena, G., La Mendola, D., Pappalard, G., Sóvágód, I., and Rizzarelli, E. (2012). Interactions of $\mathrm{Cu} 2+$ with prion family peptide fragments: considerations on affinity, speciation and coordination. Coord. Chem. Rev. 256, 2202-2218. doi: 10.1016/j.ccr.2012.03.038

Avery, S. V. (2001). Metal toxicity in yeasts and the role of oxidative stress. Adv. Appl. Microbiol. 49, 111-142. doi: 10.1016/S0065-2164(01)49011-3

Balducci, C., Beeg, M., Stravalaci, M., Bastone, A., Sclip, A., Biasini, E., et al. (2010). Synthetic amyloid-beta oligomers impair long-term memory independently of cellular prion protein. Proc. Natl. Acad. Sci. U.S.A. 107, 2295-2300. doi: 10.1073/pnas.0911829107

Bartzokis, G. (2011). Alzheimer's disease as homeostatic responses to age-related myelin breakdown. Neurobiol. Aging 32, 1341-1371. doi: 10.1016/j.neurobiolaging.2009.08.007

Bendlin, B. B., Carlsson, C. M., Gleason, C. E., Johnson, S. C., Sodhi, A., Gallagher, C. L., et al. (2010). Midlife predictors of Alzheimer's disease. Maturitas 65, 131-137. doi: 10.1016/j.maturitas.2009.12.014

Benetti, F., Ventura, M., Salmini, B., Ceola, S., Carbonera, D., Mammi, S., et al. (2010). Cuprizone neurotoxicity, copper deficiency and neurodegeneration. Neurotoxicology 31, 509-517. doi: 10.1016/j.neuro.2010.05.008

Benvegnu, S., Gasperini, L., and Legname, G. (2011). Aged PrP null mice show defective processing of neuregulins in the peripheral nervous system. Mol. Cell. Neurosci. 47, 28-35. doi: 10.1016/j.mcn.2011.02.005

Benvegnu, S., Poggiolini, I., and Legname, G. (2010). Neurodevelopmental expression and localization of the cellular prion protein in the central nervous system of the mouse. J. Comp. Neurol. 518, 1879-1891. doi: 10.1002/cne.22357

Bounhar, Y., Mann, K. K., Roucou, X., and LeBlanc, A. C. (2006). Prion protein prevents Bax-mediated cell death in the absence of other Bcl-2 family members in Saccharomyces cerevisiae. FEMS Yeast Res. 6, 1204-1212. doi: 10.1111/j.15671364.2006.00122.x

Bowen, R. L., and Atwood, C. S. (2004). Living and dying for sex. A theory of aging based on the modulation of cell cycle signaling by reproductive hormones. Gerontology 50, 265-290. doi: 10.1159/000079125
Bremer, J., Baumann, F., Tiberi, C., Wessig, C., Fischer, H., Schwarz, P., et al. (2010). Axonal prion protein is required for peripheral myelin maintenance. Nat. Neurosci. 13, 310-318. doi: 10.1038/nn.2483

Brody, H. (1955). Organization of the cerebral cortex. III. A study of aging in the human cerebral cortex. J. Comp. Neurol. 102, 511-516. doi: $10.1002 /$ cne. 901020206

Brown, D. R., and Besinger, A. (1998). Prion protein expression and superoxide dismutase activity. Biochem. J. 334(Pt 2), 423-429.

Brown, D. R., Clive, C., and Haswell, S. J. (2001). Antioxidant activity related to copper binding of native prion protein. J. Neurochem. 76, 69-76. doi: 10.1046/j.1471-4159.2001.00009.x

Brown, D. R., and Sassoon, J. (2002). Copper-dependent functions for the prion protein. Mol. Biotechnol. 22, 165-178. doi: 10.1385/MB:22:2:165

Brown, D. R., Schulz-Schaeffer, W. J., Schmidt, B., and Kretzschmar, H. A. (1997). Prion protein-deficient cells show altered response to oxidative stress due to decreased SOD-1 activity. Exp. Neurol. 146, 104-112. doi: 10.1006/exnr.1997.6505

Brown, D. R., Wong, B. S., Hafiz, F., Clive, C., Haswell, S. J., and Jones, I. M. (1999). Normal prion protein has an activity like that of superoxide dismutase. Biochem. J. 344(Pt 1), 1-5. doi: 10.1042/0264-6021:3440001

Brown, L. R., and Harris, D. A. (2003). Copper and zinc cause delivery of the prion protein from the plasma membrane to a subset of early endosomes and the Golgi. J. Neurochem. 87, 353-363. doi: 10.1046/j.1471-4159.2003.01996.x

Bueler, H., Fischer, M., Lang, Y., Bluethmann, H., Lipp, H. P., DeArmond, S. J., et al. (1992). Normal development and behaviour of mice lacking the neuronal cell-surface PrP protein. Nature 356, 577-582. doi: 10.1038/356577a0

Burke, S. N., and Barnes, C. A. (2006). Neural plasticity in the ageing brain. Nat. Rev. Neurosci. 7, 30-40. doi: 10.1038/nrn1809

Burns, A., and Iliffe, S. (2009). Alzheimer's disease. BMJ 338, b158. doi: 10.1136/bmj.b158

Calella, A. M., Farinelli, M., Nuvolone, M., Mirante, O., Moos, R., Falsig, J., et al. (2010). Prion protein and Abeta-related synaptic toxicity impairment. EMBO Mol. Med. 2, 306-314. doi: 10.1002/emmm.201000082

Chattopadhyay, M., Walter, E. D., Newell, D. J., Jackson, P. J., Aronoff-Spencer, E., Peisach, J., et al. (2005). The octarepeat domain of the prion protein binds $\mathrm{Cu}$ (II) with three distinct coordination modes at pH 7.4. J. Am. Chem. Soc. 127, 12647-12656. doi: 10.1021/ja053254z

Chung, E., Ji, Y., Sun, Y., Kascsak, R. J., Kascsak, R. B., Mehta, P. D., et al. (2010). Anti-PrPC monoclonal antibody infusion as a novel treatment for cognitive deficits in an Alzheimer's disease model mouse. BMC Neurosci. 11:130. doi: 10.1186/1471-2202-11-130

Coitinho, A. S., Roesler, R., Martins, V. R., Brentani, R. R., and Izquierdo, I. (2003). Cellular prion protein ablation impairs behavior as a function of age Neuroreport 14, 1375-1379. doi: 10.1097/01.wnr.0000078541.07662.90

Collinge, J. (2001). Prion diseases of humans and animals: their causes and molecular basis. Annu. Rev. Neurosci. 24, 519-550. doi: 10.1146/annurev.neuro. 24.1.519

Cowan, C. M., Thai, J., Krajewski, S., Reed, J. C., Nicholson, D. W., Kaufmann, S. H., et al. (2001). Caspases 3 and 9 send a pro-apoptotic signal from synapse to cell body in olfactory receptor neurons. J. Neurosci. 21, 7099-7109.

Cui, T., Daniels, M., Wong, B. S., Li, R., Sy, M. S., Sassoon, J., et al. (2003). Mapping the functional domain of the prion protein. Eur. J. Biochem. 270, 3368-3376. doi: 10.1046/j.1432-1033.2003.03717.x

DeArmond, S. J., Mobley, W. C., DeMott, D. L., Barry, R. A., Beckstead, J. H., and Prusiner, S. B. (1987). Changes in the localization of brain prion proteins during scrapie infection. Neurology 37, 1271-1280. doi: 10.1212/WNL.37.8.1271

Dohler, F., Sepulveda-Falla, D., Krasemann, S., Altmeppen, H., Schluter, H., Hildebrand, D., et al. (2014). High molecular mass assemblies of amyloid-beta oligomers bind prion protein in patients with Alzheimer's disease. Brain 137(Pt 3), 873-886. doi: 10.1093/brain/awt375

Dong, C. F., Shi, S., Wang, X. F., An, R., Li, P., Chen, J. M., et al. (2008). The Nterminus of PrP is responsible for interacting with tubulin and fCJD related PrP mutants possess stronger inhibitive effect on microtubule assembly in vitro. Arch. Biochem. Biophys. 470, 83-92. doi: 10.1016/j.abb.2007.11.007

Esiri, M. M. (2007). Ageing and the brain. J. Pathol. 211, 181-187. doi: 10.1002/path.2089

Flurkey, K., Currer, J. M., and Harrison, D. E. (2007). "The mouse in aging research," in The Mouse in Biomedical Research, Vol. 3, ed J. G. Fox (Burlington, MA: Elsevier), 637-672. 
Fournier, J. G., Escaig-Haye, F., Billette de Villemeur, T., Robain, O., Lasmezas, C. I., Deslys, J. P., et al. (1998). Distribution and submicroscopic immunogold localization of cellular prion protein $(\mathrm{PrPc})$ in extracerebral tissues. Cell Tissue Res. 292, 77-84. doi: 10.1007/s004410051036

Goh, A. X., Li, C., Sy, M. S., and Wong, B. S. (2007). Altered prion protein glycosylation in the aging mouse brain. J. Neurochem. 100, 841-854. doi: 10.1111/j.1471-4159.2006.04268.x

Goldmann, W., O’Neill, G., Cheung, F., Charleson, F., Ford, P., and Hunter, N. (1999). PrP (prion) gene expression in sheep may be modulated by alternative polyadenylation of its messenger RNA. J. Gen. Virol. 80(Pt 8), 2275-2283.

Halliwell, B. (2006). Oxidative stress and neurodegeneration: where are we now? J. Neurochem. 97, 1634-1658. doi: 10.1111/j.1471-4159.2006.03907.x

Haraguchi, T., Fisher, S., Olofsson, S., Endo, T., Groth, D., Tarentino, A., et al. (1989). Asparagine-linked glycosylation of the scrapie and cellular prion proteins. Arch. Biochem. Biophys. 274, 1-13. doi: 10.1016/0003-9861(89)90409-8

Hedden, T., and Gabrieli, J. D. (2004). Insights into the ageing mind: a view from cognitive neuroscience. Nat. Rev. Neurosci. 5, 87-96. doi: 10.1038/nrn1323

Horiuchi, M., Yamazaki, N., Ikeda, T., Ishiguro, N., and Shinagawa, M. (1995). A cellular form of prion protein (PrPC) exists in many non-neuronal tissues of sheep. J. Gen. Virol. 76(Pt 10), 2583-2587. doi: 10.1099/0022-1317-76-10-2583

Hornshaw, M. P., McDermott, J. R., and Candy, J. M. (1995). Copper binding to the N-terminal tandem repeat regions of mammalian and avian prion protein. Biochem. Biophys. Res. Commun. 207, 621-629. doi: 10.1006/bbrc.1995.1233

Jackson, G. S., Murray, I., Hosszu, L. L., Gibbs, N., Waltho, J. P., Clarke, A. R., et al. (2001). Location and properties of metal-binding sites on the human prion protein. Proc. Natl. Acad. Sci. U.S.A. 98, 8531-8535. doi: 10.1073/pnas.151038498

Kellett, K. A., and Hooper, N. M. (2009). Prion protein and Alzheimer disease. Prion 3, 190-194. doi: 10.4161/pri.3.4.9980

Kessels, H. W., Nguyen, L. N., Nabavi, S., and Malinow, R. (2010). The prion protein as a receptor for amyloid-beta. Nature 466, E3-E4. discussion: E-5. doi: 10.1038 /nature09217

Kitamoto, T., Iizuka, R., and Tateishi, J. (1993). An amber mutation of prion protein in Gerstmann-Straussler syndrome with mutant PrP plaques. Biochem. Biophys. Res. Commun. 192, 525-531. doi: 10.1006/bbrc.1993.1447

Kralovicova, S., Fontaine, S. N., Alderton, A., Alderman, J., Ragnarsdottir, K. V., Collins, S. J., et al. (2009). The effects of prion protein expression on metal metabolism. Mol. Cell. Neurosci. 41, 135-147. doi: 10.1016/j.mcn.2009.02.002

Lasmezas, C. I., Deslys, J. P., Robain, O., Jaegly, A., Beringue, V., Peyrin, J. M., et al. (1997). Transmission of the BSE agent to mice in the absence of detectable abnormal prion protein. Science 275, 402-405. doi: 10.1126/science.275.5298.402

Lauren, J., Gimbel, D. A., Nygaard, H. B., Gilbert, J. W., and Strittmatter, S. M. (2009). Cellular prion protein mediates impairment of synaptic plasticity by amyloid-beta oligomers. Nature 457, 1128-1132. doi: 10.1038/nature 07761

Lehmann, S., and Harris, D. A. (1997). Blockade of glycosylation promotes acquisition of scrapie-like properties by the prion protein in cultured cells. J. Biol. Chem. 272, 21479-21487. doi: 10.1074/jbc.272.34.21479

Liu, L., Jiang, D., McDonald, A., Hao, Y., Millhauser, G. L., and Zhou, F. (2011). Copper redox cycling in the prion protein depends critically on binding mode. J. Am. Chem. Soc. 133, 12229-12237. doi: 10.1021/ja2045259

Lo, R. Y., Shyu, W. C., Lin, S. Z., Wang, H. J., Chen, S. S., and Li, H. (2007). New molecular insights into cellular survival and stress responses: neuroprotective role of cellular prion protein (PrPC). Mol. Neurobiol. 35, 236-244. doi: 10.1007/s12035-007-8003-y

Malaga-Trillo, E., Solis, G. P., Schrock, Y., Geiss, C., Luncz, L., Thomanetz, V., et al. (2009). Regulation of embryonic cell adhesion by the prion protein. PLoS Biol. 7:e55. doi: 10.1371/journal.pbio. 1000055

Martin, M., Dotti, C. G., and Ledesma, M. D. (2010). Brain cholesterol in normal and pathological aging. Biochim. Biophys. Acta 1801, 934-944. doi: 10.1016/j.bbalip.2010.03.011

Martin, M. G., Perga, S., Trovo, L., Rasola, A., Holm, P., Rantamaki, T., et al. (2008). Cholesterol loss enhances TrkB signaling in hippocampal neurons aging in vitro. Mol. Biol. Cell 19, 2101-2112. doi: 10.1091/mbc.E07-09-0897

Massimino, M. L., Redaelli, M., Bertoli, A., Sorgato, M. C., and Mucignat-Caretta, C. (2013). Altered behavioral aspects of aged mice lacking the cellular prion protein. Physiol. Behav. 119, 86-91. doi: 10.1016/j.physbeh.2013.06.006

McLennan, N. F., Brennan, P. M., McNeill, A., Davies, I., Fotheringham, A., Rennison, K. A., et al. (2004). Prion protein accumulation and neuroprotection in hypoxic brain damage. Am. J. Pathol. 165, 227-235. doi: 10.1016/S00029440(10)63291-9

Meyne, F., Gloeckner, S. F., Ciesielczyk, B., Heinemann, U., Krasnianski, A., Meissner, B., et al. (2009). Total prion protein levels in the cerebrospinal fluid are reduced in patients with various neurological disorders. J. Alzheimers. Dis. 17, 863-873. doi: 10.3233/JAD-2009-1110

Mitsios, N., Saka, M., Krupinski, J., Pennucci, R., Sanfeliu, C., Miguel Turu, M., et al. (2007). Cellular prion protein is increased in the plasma and periinfarcted brain tissue after acute stroke. J. Neurosci. Res. 85, 602-611. doi: 10.1002/jnr.21142

Miura, T., Sasaki, S., Toyama, A., and Takeuchi, H. (2005). Copper reduction by the octapeptide repeat region of prion protein: $\mathrm{pH}$ dependence and implications in cellular copper uptake. Biochemistry 44, 8712-8720. doi: 10.1021/bi0501784

Morales, R., Estrada, L. D., Diaz-Espinoza, R., Morales-Scheihing, D., Jara, M. C., Castilla, J., et al. (2010). Molecular cross talk between misfolded proteins in animal models of Alzheimer's and prion diseases. J. Neurosci. 30, 4528-4535. doi: 10.1523/JNEUROSCI.5924-09.2010

Moudjou, M., Bernard, J., Sabuncu, E., Langevin, C., and Laude, H. (2007). Glycan chains modulate prion protein binding to immobilized metal ions. Neurochem. Int. 50, 689-695. doi: 10.1016/j.neuint.2007.01.001

Moudjou, M., Frobert, Y., Grassi, J., and La Bonnardière, C. (2001). Cellular prion protein status in sheep: tissue-specific biochemical signatures. J. Gen. Virol. 82(Pt 8), 2017-2024. doi: 10.1099/vir.0.17776-0

Nazor, K. E., Seward, T., and Telling, G. C. (2007). Motor behavioral and neuropathological deficits in mice deficient for normal prion protein expression. Biochim. Biophys. Acta 1772, 645-653. doi: 10.1016/j.bbadis.2007.04.004

Ordonez-Gutierrez, L., Torres, J. M., Gavin, R., Anton, M., Arroba-Espinosa, A. I., Espinosa, J. C., et al. (2013). Cellular prion protein modulates beta-amyloid deposition in aged APP/PS1 transgenic mice. Neurobiol. Aging 34, 2793-2804. doi: 10.1016/j.neurobiolaging.2013.05.019

Pan, T., Li, R., Kang, S. C., Pastore, M., Wong, B. S., Ironside, J., et al. (2005a). Biochemical fingerprints of prion diseases: scrapie prion protein in human prion diseases that share prion genotype and type. J. Neurochem. 92, 132-142. doi: 10.1111/j.1471-4159.2004.02859.x

Pan, T., Li, R., Wong, B. S., Kang, S. C., Ironside, J., and Sy, M. S. (2005b). Novel antibody-lectin enzyme-linked immunosorbent assay that distinguishes prion proteins in sporadic and variant cases of Creutzfeldt-Jakob disease. J. Clin. Microbiol. 43, 1118-1126. doi: 10.1128/JCM.43.3.1118-1126.2005

Pan, T., Li, R., Wong, B. S., Liu, T., Gambetti, P., and Sy, M. S. (2002). Heterogeneity of normal prion protein in two- dimensional immunoblot: presence of various glycosylated and truncated forms. J. Neurochem. 81, 1092-1101. doi: 10.1046/j.1471-4159.2002.00909.x

Pan, T., Wong, P., Chang, B., Li, C., Li, R., Kang, S. C., et al. (2005c). Biochemical fingerprints of prion infection: accumulations of aberrant full-length and $\mathrm{N}$ terminally truncated PrP species are common features in mouse prion disease. J. Virol. 79, 934-943. doi: 10.1128/JVI.79.2.934-943.2005

Parkin, E. T., Watt, N. T., Hussain, I., Eckman, E. A., Eckman, C. B., Manson, J. C., et al. (2007). Cellular prion protein regulates beta-secretase cleavage of the Alzheimer's amyloid precursor protein. Proc. Natl. Acad. Sci. U.S.A. 104, 11062-11067. doi: 10.1073/pnas.0609621104

Pauly, P. C., and Harris, D. A. (1998). Copper stimulates endocytosis of the prion protein. J. Biol. Chem. 273, 33107-33110. doi: 10.1074/jbc.273.50.33107

Peralta, O. A., Huckle, W. R., and Eyestone, W. H. (2012). Developmental expression of the cellular prion protein $(\operatorname{PrP}(\mathrm{C}))$ in bovine embryos. Mol. Reprod. Dev. 79, 488-498. doi: 10.1002/mrd.22057

Peters, A. (2002). The effects of normal aging on myelin and nerve fibers: a review. J. Neurocytol. 31, 581-593. doi: 10.1023/A:1025731309829

Prusiner, S. B. (1991). Molecular biology and transgenetics of prion diseases. Crit. Rev. Biochem. Mol. Biol. 26, 397-438. doi: 10.3109/10409239109086789

Prusiner, S. B. (1994). Biology and genetics of prion diseases. Annu. Rev. Microbiol. 48, 655-686. doi: 10.1146/annurev.mi.48.100194.003255

Prusiner, S. B. (2001). Shattuck lecture-neurodegenerative diseases and prions. N. Engl. J. Med. 344, 1516-1526. doi: 10.1056/NEJM200105173442006

Querfurth, H. W., and LaFerla, F. M. (2010). Alzheimer's disease. N. Engl. J. Med. 362, 329-344. doi: 10.1056/NEJMra0909142

Rachidi, W., Vilette, D., Guiraud, P., Arlotto, M., Riondel, J., Laude, H., et al. (2003). Expression of prion protein increases cellular copper binding and antioxidant enzyme activities but not copper delivery. J. Biol. Chem. 278, 9064-9072. doi: 10.1074/jbc.M211830200 
Rial, D., Duarte, F. S., Xikota, J. C., Schmitz, A. E., Dafre, A. L., Figueiredo, C. P., et al. (2009). Cellular prion protein modulates age-related behavioral and neurochemical alterations in mice. Neuroscience 164, 896-907. doi: 10.1016/j.neuroscience.2009.09.005

Roucou, X., and LeBlanc, A. C. (2005). Cellular prion protein neuroprotective function: implications in prion diseases. J. Mol. Med. (Berl.) 83, 3-11. doi: 10.1007/s00109-004-0605-5

Safar, J., Wang, W., Padgett, M. P., Ceroni, M., Piccardo, P., Zopf, D., et al. (1990). Molecular mass, biochemical composition, and physicochemical behavior of the infectious form of the scrapie precursor protein monomer. Proc. Natl. Acad. Sci. U.S.A. 87, 6373-6377. doi: 10.1073/pnas.87.16.6373

Saijo, E., Scheff, S. W., and Telling, G. C. (2011). Unaltered prion protein expression in Alzheimer disease patients. Prion 5, 109-116. doi: 10.4161/pri.5.2.16355

Sales, N., Hassig, R., Rodolfo, K., Di Giamberardino, L., Traiffort, E., Ruat, M., et al. (2002). Developmental expression of the cellular prion protein in elongating axons. Eur. J. Neurosci. 15, 1163-1177. doi: 10.1046/j.1460-9568.2002.01953.x

Scheibel, A. B. (1979). Dendritic changes in senile and presenile dementias. Res. Publ. Assoc. Res. Nerv. Ment. Dis. 57, 107-124.

Scheibel, M. E., Lindsay, R. D., Tomiyasu, U., and Scheibel, A. B. (1976). Progressive dendritic changes in the aging human limbic system. Exp. Neurol. 53, 420-430. doi: 10.1016/0014-4886(76)90082-0

Schmitz, M., Greis, C., Ottis, P., Silva, C. J., Schulz-Schaeffer, W. J., Wrede, A., et al. (2014). Loss of prion protein leads to age-dependent behavioral abnormalities and changes in cytoskeletal protein expression. Mol. Neurobiol. doi: 10.1007/s12035-014-8655-3. [Epub ahead of print].

Schwarze-Eicker, K., Keyvani, K., Gortz, N., Westaway, D., Sachser, N., and Paulus, W. (2005). Prion protein $(\mathrm{PrPc})$ promotes beta-amyloid plaque formation. Neurobiol. Aging 26, 1177-1182. doi: 10.1016/j.neurobiolaging.2004.10.004

Shyu, W. C., Chen, C. P., Saeki, K., Kubosaki, A., Matusmoto, Y., Onodera, T., et al. (2005). Hypoglycemia enhances the expression of prion protein and heat-shock protein 70 in a mouse neuroblastoma cell line. J. Neurosci. Res. 80, 887-894. doi: 10.1002/jnr.20509

Shyu, W. C., Kao, M. C., Chou, W. Y., Hsu, Y. D., and Soong, B. W. (2000). Heat shock modulates prion protein expression in human NT-2 cells. Neuroreport 11, 771-774. doi: 10.1097/00001756-200003200-00023

Shyu, W. C., Lin, S. Z., Saeki, K., Kubosaki, A., Matsumoto, Y., Onodera, T., et al. (2004). Hyperbaric oxygen enhances the expression of prion protein and heat shock protein 70 in a mouse neuroblastoma cell line. Cell. Mol. Neurobiol. 24, 257-268. doi: 10.1023/B:CEMN.0000018620.41913.d2

Singh, A., Kong, Q., Luo, X., Petersen, R. B., Meyerson, H., and Singh, N. (2009). Prion protein (PrP) knock-out mice show altered iron metabolism: a functional role for PrP in iron uptake and transport. PLoS ONE 4:e6115. doi: 10.1371/journal.pone.0006115

Singh, N., Das, D., Singh, A., and Mohan, M. L. (2010). Prion protein and metal interaction: physiological and pathological implications. Curr. Issues Mol. Biol. 12, 99-107.

Skripuletz, T., Lindner, M., Kotsiari, A., Garde, N., Fokuhl, J., Linsmeier, F., et al. (2008). Cortical demyelination is prominent in the murine cuprizone model and is strain-dependent. Am. J. Pathol. 172, 1053-1061. doi: 10.2353/ajpath.2008.070850

Stahl, N., Baldwin, M. A., Burlingame, A. L., and Prusiner, S. B. (1990). Identification of glycoinositol phospholipid linked and truncated forms of the scrapie prion protein. Biochemistry 29, 8879-8884. doi: 10.1021/bi00490a001

Stockel, J., Safar, J., Wallace, A. C., Cohen, F. E., and Prusiner, S. B. (1998). Prion protein selectively binds copper(II) ions. Biochemistry 37, 7185-7193. doi: 10.1021/bi972827k
Thibault, O., Hadley, R., and Landfield, P. W. (2001). Elevated postsynaptic [Ca2+]i and L-type calcium channel activity in aged hippocampal neurons: relationship to impaired synaptic plasticity. J. Neurosci. 21, 9744-9756.

Treiber, C., Pipkorn, R., Weise, C., Holland, G., and Multhaup, G. (2007). Copper is required for prion protein-associated superoxide dismutase-I activity in Pichia pastoris. FEBS J. 274, 1304-1311. doi: 10.1111/j.1742-4658.2007.05678.x

Trovo, L., Van Veldhoven, P. P., Martin, M. G., and Dotti, C. G. (2011). Sphingomyelin upregulation in mature neurons contributes to TrkB activity by Racl endocytosis. J. Cell Sci. 124(Pt 8), 1308-1315. doi: 10.1242/jcs.078766

Vassallo, N., and Herms, J. (2003). Cellular prion protein function in copper homeostasis and redox signalling at the synapse. J. Neurochem. 86, 538-544. doi: 10.1046/j.1471-4159.2003.01882.x

Verdu, E., Ceballos, D., Vilches, J. J., and Navarro, X. (2000). Influence of aging on peripheral nerve function and regeneration. J. Peripher. Nerv. Syst. 5, 191-208. doi: 10.1046/j.1529-8027.2000.00026.x

Watt, N. T., Taylor, D. R., Gillott, A., Thomas, D. A., Perera, W. S., and Hooper, N. M. (2005). Reactive oxygen species-mediated beta-cleavage of the prion protein in the cellular response to oxidative stress. J. Biol. Chem. 280, 35914-35921. doi: 10.1074/jbc.M507327200

Whitehouse, I. J., Jackson, C., Turner, A. J., and Hooper, N. M. (2010). Prion protein is reduced in aging and in sporadic but not in familial Alzheimer's disease. J. Alzheimers. Dis. 22, 1023-1031. doi: 10.3233/JAD-2010-101071

Williams, W. M., Stadtman, E. R., and Moskovitz, J. (2004). Ageing and exposure to oxidative stress in vivo differentially affect cellular levels of PrP in mouse cerebral microvessels and brain parenchyma. Neuropathol. Appl. Neurobiol. 30, 161-168. doi: 10.1111/j.1365-2990.2003.00523.x

Wong, B. S., Liu, T., Li, R., Pan, T., Petersen, R. B., Smith, M. A., et al. (2001). Increased levels of oxidative stress markers detected in the brains of mice devoid of prion protein. J. Neurochem. 76, 565-572. doi: 10.1046/j.14714159.2001.00028.x

Yoshioka, Y., Ishiguro, N., and Inoshima, Y. (2010). Proteasome activity and biological properties of normal prion protein: a comparison between young and aged cattle. J. Vet. Med. Sci. 72, 1583-1587. doi: 10.1292/jvms.10-0149

Zahn, R., Liu, A., Luhrs, T., Riek, R., von Schroetter, C., Lopez Garcia, F., et al. (2000). NMR solution structure of the human prion protein. Proc. Natl. Acad. Sci. U.S.A. 97, 145-150. doi: 10.1073/pnas.97.1.145

Zhu, X., Su, B., Wang, X., Smith, M. A., and Perry, G. (2007). Causes of oxidative stress in Alzheimer disease. Cell. Mol. Life Sci. 64, 2202-2210. doi: 10.1007/s00018-007-7218-4

Conflict of Interest Statement: The authors declare that the research was conducted in the absence of any commercial or financial relationships that could be construed as a potential conflict of interest.

Received: 30 June 2014; paper pending published: 18 July 2014; accepted: 09 August 2014; published online: 29 August 2014.

Citation: Gasperini L and Legname G (2014) Prion protein and aging. Front. Cell Dev. Biol. 2:44. doi: 10.3389/fcell.2014.00044

This article was submitted to Cell Death and Survival, a section of the journal Frontiers in Cell and Developmental Biology.

Copyright (c) 2014 Gasperini and Legname. This is an open-access article distributed under the terms of the Creative Commons Attribution License (CC BY). The use, distribution or reproduction in other forums is permitted, provided the original author(s) or licensor are credited and that the original publication in this journal is cited, in accordance with accepted academic practice. No use, distribution or reproduction is permitted which does not comply with these terms. 